\title{
PROFIL KADAR MDA PADA TUMOR KULIT MENCIT (Mus musculus) SEBAGAI AKIBAT PEMBERIAN EKSTRAK ETANOL DAUN SIRSAK (Annona muricata L) DAN EKSTRAK METANOL BENALU TEH (Scurulla atropurpurea BI. Dancer)
}

\author{
Kholifah Holil \\ Jurusan Biologi, Fakultas Sains dan Teknologi \\ Universitas Islam Negeri (UIN) Maulana Malik Ibrahim Malang \\ Email: ifa_biomolrep03@yahoo.com
}

\begin{abstract}
Malondialdehyde (MDA) is widely used as an indicator of lipid peroxidation. Increased levels of MDA have been associated with a variety of tumor diseases, one of is a skin tumor. To cope with this disease use several medicinal plants which are leaves of soursop (Annona muricata L) and tea parasite (Scurulla atropurpurea Bl. dancer). This study aims to determine the profile of MDA in mouse skin tumors as a result of ethanol extract of leaves of soursop and methanol extract of tea parasite. The sample used in this study were mouse skin tumors derived from mice induced by using 7.12 - Dimethilbenz( $(\alpha)$ Antrasen (DMBA) and ethanol extract of leaves of soursop and methanol extract of tea parasite. While the observation parameters are obtained via MDA spectrophotometer method. The result of this research showed that the levels of MDA in mouse skin tumors induced ethanol extract of leaves of soursop and methanol extract of tea parasite is different. Lowest MDA levels $(34.95 \mathrm{nmol} / \mathrm{g}$ ) contained in the DS3 that comes from DMBA-induced mice $25 \mu \mathrm{g} / 100 \mu \mathrm{l}$ of acetone and ethanol extracts of soursop leaf $60 \mathrm{mg} / \mathrm{kg}$.
\end{abstract}

Keywords: Malondialdehyde (MDA), Tumor, Lipid peroxidation, Soursop, Tea Parasite, Mouse, and DMBA

\section{PENDAHULUAN}

Penyakit tumor adalah penyakit yang disebabkan oleh adanya pertumbuhan sel yang tidak terkendali. Salah satu penyebab tidak terkendalinya pertumbuhan sel tersebut adalah karena adanya radikal bebas. Radikal bebas dapat diinduksi dengan berbagai bahan kimia, salah satu antara lain diinduksi dengan 7,12Dimethilbenz( $\alpha$ )Antrasen (DMBA). Menurut Susilowati (2010) senyawa DMBA merupakan salah satu senyawa golongan hidrokarbon aromatik polisiklik (PAH) yang bersifat karsinogenik. Mekanisme aksi yang dihasilkan oleh senyawa ini terjadi sebagai akibat DMBA berikatan dengan reseptor Arylhydrocarbon Receptor (AhR) (Akrom, 2012). Salah satu produk yang dihasilkan sebagai akibat yang ditimbulkan oleh adanya ikatan antara DMBA dengan AhR adalah berikatannya malondialdehyde dengan basa nitrogen pada DNA sehingga menyebabkan kerusakan pada DNA dan menginduksi gen-gen penting penginisiasi kanker (Susilowati, 2010) dan selanjutnya berakibat pada perubahan sel menjadi aktif berproliferasi. Salah satu efek yang ditimbulkan ini menurut Dandekar et al. (1986) terjadi pada gen Harvey Ras-1 pada kodon 61 kanker payudara dan kanker kulit.

Untuk mengatasi adanya radikal bebas penyebab tumor maka dapat digunakan berbagai tanaman yang memiliki potensi antioksidan sehingga proliferasi sel dapat dikendalikan dan pada akhirnya resiko tumor dapat dicegah. Sirsak (Annona muricata L.) adalah salah satu tanaman yang bermanfaat untuk mengatasi berbagai penyakit. Hasil riset menunjukkan bahwa sirsak mampu menyembuhkan sakit jantung, asma, masalah liver (hati), dan rematik (Widyaningrum, 2011) serta mampu menyembuhkan berbagai kanker maupun tumor (Adewole, 2006; Chang, 2003; Wu et al., 2001). Hal ini dimungkinkan karena sirsak mengandung tanin, alkaloid, dan flavonoid (Kardinan, 2004).

Tanaman lain yang juga memiliki potensi sebagai antioksidan yang dapat mengikat radikal bebas adalah benalu teh (Scurulla atropurpurea). Tanaman ini dikenal sebagai tanaman parasit yang menempel pada teh dan belum banyak dimanfaatkan. 
Kandungan yang dimiliki oleh benalu teh dapat dijadikan sebagai bahan untuk mengatasi berbagai penyakit ataupun untuk kepentingan lain. Senyawa kimia yang dimiliki oleh tanaman ini diantaranya adalah alkaloid, flavonoid, terpenoid, glikosida, triterpen, saponin, dan tanin (Nugroho et al., 2000; Tambunan et al., 2003; Ohashi, 2003; Sulistio, 2008). Penelitian ini dilakukan dengan tujuan untuk mengetahui profil kadar MDA pada tumor kulit mencit sebagai akibat pemberian ekstrak etanol daun sirsak dan ekstrak metanol benalu teh sehingga diharapkan potensi yang dimiliki oleh tanaman dapat diketahui lebih dalam. Kadar MDA yang dihasilkan akan menggambarkan potensi tanaman yang digunakan tersebut dalam mengikat radikal bebas penyebab tumor pada kulit mencit yang diinduksi dengan DMBA.

\section{BAHAN DAN METODE Alat dan Bahan}

Alat-alat yang digunakan dalam penelitian ini adalah kandang hewan coba (bak plastik), kawat, tempat makan, tempat minum, beaker glass, erlenmeyer, gelas ukur, kertas saring, timbangan digital, ayakan tepung, papan bedah, pipet tetes, gunting, pinset, pengaduk kaca, corong Buchner, rotary evaporator, freezer, sonde lambung yang dimodifikasi, mikropipet, tip, sentrifius, tabung ukuran $1.5 \mathrm{ml}$, spuit ukuran $1 \mathrm{ml}$, hand glove, masker, dan spektrofotometer.

Sedangkan bahan yang digunakan dalam penelitian ini adalah mencit (Mus musculus) galur Balb/c jenis kelamin jantan, pakan, serbuk kayu (sekam), air, daun sirsak (Annona muricata L), benalu teh (Scurulla atropurpurea), DMBA, kloroform, metanol, etanol absolut, kit MDA, aquades, kapas, dan tisu.

\section{METODE}

Secara umum penelitian ini dilakukan melalui 3 tahap. Tahap-tahap dalam penelitian ini diantaranya yaitu tahap persiapan, tahap pelaksanaan, dan tahap pengambilan data.

Tahap persiapan meliputi tahap persiapan hewan coba dan tahap ekstraksi daun sirsak dan benalu teh. Pada persiapan hewan coba, mencit diaklimasi selama 2 minggu pada suhu kamar $\left(20-25^{\circ} \mathrm{C}\right)$. Sedangkan proses ekstraksi dilakukan dengan metode maserasi dimana serbuk daun sirsak dan benalu teh dimaserasi dengan etanol $70 \%$ selama 24 jam, disaring dengan pompa vakum dan corong buchner dan selanjutnya diuapkan dengan menggunakan rotary evaporator. Ekstrak yang didapatkan selanjutnya digunakan sesuai dengan perlakuan yang ditetapkan.

Tahap pelaksanaan meliputi tahap pemeliharaan hewan coba dan pemberian perlakuan. Pada tahap ini, mencit diinduksi DMBA dengan cara subkutan sebanyak 2 kali dalam seminggu selama 6 minggu dan diberi ekstrak etanol daun sirsak dan ekstrak metanol benalu teh yang diberikan setiap hari (minggu ke-7 sampai minggu ke-12). Beberapa perlakuan yang dimaksud dalam penelitian ini adalah kontrol negatif yaitu mencit yang tidak dinduksi dengan DMBA konsentrasi $25 \mu \mathrm{g} / 100 \mu \mathrm{l}$ aseton dan juga tidak diberi ekstrak etanol daun sirsak dan ekstrak metanol benalu teh, kontrol positif yaitu mencit yang diinduksi dengan DMBA konsentrasi $25 \mu \mathrm{g} / 100 \mu 1$ aseton, DS 1 yaitu mencit yang diinduksi dengan DMBA konsentrasi $25 \mu \mathrm{g} / 100 \mu \mathrm{l}$ aseton dan diberi ekstrak etanol daun sirsak $30 \mathrm{mg} / \mathrm{KgBB}$. Sedangkan DS 2 yaitu mencit yang diinduksi dengan DMBA konsentrasi $25 \mu \mathrm{g} / 100 \mu \mathrm{l}$ aseton dan diberi ekstrak etanol daun sirsak $60 \mathrm{mg} / \mathrm{KgBB}$ serta DS 3 yaitu mencit yang diinduksi DMBA konsentrasi $25 \mu \mathrm{g} / 100 \mu \mathrm{l}$ aseton dan diberi ekstrak etanol daun sirsak $60 \mathrm{mg} / \mathrm{KgBB}$. Selanjutnya perlakuan lain selain di atas adalah BT 1 yaitu mencit yang diinduksi DMBA $25 \mu \mathrm{g} / 100 \mu \mathrm{l}$ aseton dan diberi ekstrak benalu teh $750 \mathrm{mg} / \mathrm{KgBB}$, BT 2 yaitu mencit yang diinduksi DMBA $25 \mu \mathrm{g} / 100 \mu \mathrm{l}$ aseton dan diberi ekstrak benalu teh $1500 \mathrm{mg} / \mathrm{KgBB}$, dan BT 3 yaitu mencit yang diinduksi dengan DMBA $25 \mu \mathrm{g} / 100 \mu \mathrm{l}$ aseton dan diberi ekstrak benalu teh $2250 \mathrm{mg} / \mathrm{KgBB}$.

Tahap pengambilan data meliputi tahap isolasi darah dan tahap pengukuran kadar MDA. Darah dari mencit yang diberi perlakuan diambil untuk kemudian dipisahkan melalui proses sentrifugasi. Hasil yang didapatkan dari proses sentrifugasi adalah serum yang kemudian digunakan dalam pengukuran kadar MDA dengan metode spektrofotometer.

\section{HASIL DAN PEMBAHASAN}

Hasil penelitian profil kadar MDA menunjukkan adanya perbedaan hasil kadar MDA yang dihasilkan. Tabel 1 di bawah ini menunjukkan kadar MDA tumor kulit mencit 
sebagai akibat pemberian ekstrak etanol daun sirsak yang dimaksud:

Tabel 1. Kadar MDA tumor kulit mencit sebagai akibat pemberian ekstrak etanol daun sirsak (Annona muricata L)

\begin{tabular}{llllll}
\hline $\begin{array}{l}\text { Perlak } \\
\text { uan }\end{array}$ & \multicolumn{2}{l}{$\begin{array}{l}\text { Kadar } \\
\text { pada ulangan ke..... }\end{array}$} & \\
\cline { 2 - 5 } & $\mathbf{1}$ & $\mathbf{2}$ & $\mathbf{3}$ & $\mathbf{4}$ & \\
\hline Kontrol & 48.2 & 49.2 & 59.2 & 58.2 & 53.75 \\
positif & 1 & 9 & 9 & 1 & \\
\hline DS 1 & 50.5 & 50.0 & 42.1 & 41.4 & 46.03 \\
& 4 & 0 & 4 & 3 & \\
\hline DS 2 & 43.3 & 43.9 & 37.8 & 37.3 & 40.62 \\
& 9 & 3 & 6 & 2 & \\
\hline DS 3 & 47.6 & 47.3 & 22.5 & 22.3 & 34.95 \\
& 8 & 2 & 0 & 2 & \\
\hline Kontrol & 5.71 & 4.64 & 3.57 & 3.21 & 4.28 \\
negatif & & & & & \\
\hline
\end{tabular}

Berdasarkan tabel 1 di atas terlihat bahwa kadar MDA yang dihasilkan sebagai akibat pemberian ekstrak etanol daun sirsak berbeda-beda antar perlakuan. Kadar MDA pada kontrol terlihat memiliki kadar MDA yang paling tinggi dibandingkan perlakuan lain. Hal ini disebabkan karena mencit yang ada pada kontrol hanya diinduksi dengan DMBA $25 \mu \mathrm{g} / 100 \mu \mathrm{l}$ aseton tanpa diberi ekstrak etanol daun sirsak. Pemberian DMBA dilakukan untuk menginduksi terjadinya radikal bebas. Terdapatnya radikal bebas ini agar stabil perlu untuk diikat dengan antioksidan baik antioksidan endogen maupun eksogen. Ekstrak etanol daun sirsak mengandung tanin, alkaloid, dan flavonoid (Kardinan, 2004). Dari beberapa senyawa yang terkandung dalam sirsak, flavonoid merupakan antioksidan eksogen yang mampu mengendalikan radikal bebas. Senyawa ini akan memberikan atom hidrogen pada radikal bebas (Fessenden, 1999) dan menghambat transport elektron mitokondria (Complex ${ }^{1}$ ) (Woo, 2000) sehingga radikal bebas yang dihasilkan sebagai akibat pemberian DMBA menjadi stabil dan sebagai akibatnya kadar MDA menjadi relatif lebih rendah. Selain itu penghambatan transport elektron mitokondria (Complex ${ }^{1}$ ) dan penghambatan membran plasma NADH oksidase pada sel kanker (Woo, 2000) akan menghambat produksi ATP pada sel kanker sehingga jumlah ATP yang terbentuk menjadi rendah dan proliferasi sel menjadi terhambat.
Kadar MDA yang terbentuk sangat bergantung pada jumlah radikal bebas yang mampu dinetralisasi oleh antioksidan yang ada. Pada kondisi normal kadar MDA yang terbentuk ada pada kadar rendah. Hal ini ditunjukkan pada tabel 1 dimana kadar MDA yang terbentuk dibandingkan dengan mencit yang tidak diberi ekstrak etanol daun sirsak paling rendah yaitu hanya sebesar $4.28 \mathrm{nmol} / \mathrm{g}$. Selain itu ada perbedaan kadar MDA yang dihasilkan pada perlakuan mencit yang diberi ekstrak etanol daun sirsak dengan kadar MDA yang dihasilkan pada perlakuan mencit yang diberi ekstrak metanol benalu teh . Tabel 2 di bawah ini menunjukkan kadar MDA pada mencit yang diberi ekstrak metanol benalu teh.

Tabel 2. Kadar MDA tumor kulit mencit sebagai akibat pemberian ekstrak metanol benalu teh (Scurulla atropurpurea)

\begin{tabular}{llllll}
\hline \multirow{2}{*}{$\begin{array}{l}\text { Perlak } \\
\text { uan }\end{array}$} & \multicolumn{2}{l}{$\begin{array}{l}\text { Kadar } \\
\text { pada ulangan ke...... }\end{array}$} & \\
\cline { 2 - 4 } & $\mathbf{1}$ & $\mathbf{2}$ & $\mathbf{3}$ & $\mathbf{4}$ & \\
\hline Kontrol & 48.2 & 49.2 & 59.2 & 58.2 & 53.75 \\
positif & 1 & 9 & 9 & 1 & \\
\hline BT 1 & 46.2 & 45.7 & 52.6 & 51.9 & 49.15 \\
& 5 & 1 & 8 & 6 & \\
\hline BT 2 & 55.8 & 56.4 & 40.1 & 40.7 & 48.30 \\
& 9 & 3 & 8 & 1 & \\
\hline BT 3 & 47.9 & 49.2 & 48.2 & 47.6 & 48.27 \\
& 6 & 3 & 1 & 8 & \\
\hline Kontrol & 5.71 & 4.64 & 3.57 & 3.21 & 4.28 \\
negatif & & & & & \\
\hline
\end{tabular}

Pada tabel 2 di atas menunjukkan bahwa kadar MDA pada mencit yang diinduksi DMBA dan diberi ekstrak metanol benalu teh (Scurulla atropurpurea) juga menunjukkan kadar yang berbeda-beda. Kadar MDA pada kelompok benalu teh berbeda dengan kadar MDA pada kelompok kontrol positif maupun pada kontrol negatif. Pada kelompok kontrol positif menunjukkan kadar MDA paling tinggi yaitu sebesar $53.75 \mathrm{nmol} / \mathrm{g}$, sedangkan pada kontrol negatif menunjukkan kadar MDA yang paling rendah yaitu sebesar $4.28 \mathrm{nmol} / \mathrm{g}$. Pada kelompok perlakuan yang diberi ekstrak metanol benalu teh menunjukkan semakin tinggi dosis yang diberikan maka kadar MDA yang dihasilkan semakin rendah.

Perbedaan kadar MDA yang dihasilkan tersebut merupakan indikator terjadinya radikal bebas yang direspon berbeda-beda oleh sel. Pemberian ekstrak 
metanol benalu teh dengan kandungan berupa alkaloid, flavonoid, terpenoid, glikosida, triterpen, saponin, dan tanin (Nugroho et al., 2000 dan Tambunan et al., 2003) mampu mengikat radikal bebas yang terbentuk sebagai akibat induksi DMBA. Namun demikian, secara umum kadar MDA yang dihasilkan sebagai akibat pemberian ekstrak metanol benalu teh masih tergolong lebih tinggi dibandingkan dengan kadar MDA yang dihasilkan pada perlakuan ekstrak etanol daun sirsak. Kadar MDA pada BT 3 yaitu mencit yang diinduksi dengan DMBA $25 \mu \mathrm{g} / 100 \mu \mathrm{l}$ aseton dan diberi ekstrak benalu teh 2250 $\mathrm{mg} / \mathrm{KgBB}$ masih tergolong tinggi (48.27 $\mathrm{nmol} / \mathrm{g}$ ) dibandingkan dengan DS3 yang berasal dari mencit yang diinduksi DMBA konsentrasi $25 \mu \mathrm{g} / 100 \mu \mathrm{l}$ aseton dan diberi ekstrak etanol daun sirsak $60 \mathrm{mg} / \mathrm{KgBB}$. Kadar MDA pada DS 3 hanya sebesar $34.95 \mathrm{nmol} / \mathrm{g}$. Perbedaan kadar MDA antara mencit yang diberi perlakuan DS3 dengan mencit yang diberi perlakuan BT3 dimungkinkan karena kadar bahan aktif yang berperan sebagai antioksidan pada kedua tanaman yang digunakan juga berbeda. Selain hal di atas, perbedaan kadar yang dihasilkan juga disebabkan karena dosis yang digunakan masih perlu untuk dieksplorasi lebih lanjut agar memiliki kemampuan yang lebih dalam menurunkan kadar MDA sehingga dapat mendekati kadar MDA sebagaimana dihasilkan pada mencit kontrol negatif yaitu sebesar 4.28 nmol/g. Namun demikian, penelitian ini membuktikan terdapatnya potensi yang dimiliki oleh ekstrak etanol daun sirsak dan ekstrak metanol benalu teh sebagai tanaman yang memiliki kandungan antioksidan yang bermanfaat dalam mengendalikan radikal bebas penyebab tumor kulit. Kemampuan yang dimiliki kedua tanaman tersebut juga didukung oleh data lain yang diteliti oleh Sani (2013) tentang Uji Aktivitas Antitumor Ekstrak Etanol Daun Sirsak Pada Kulit Mencit (Mus musculus) yang diinduksi 7,12Dimetilbenz $(\alpha)$ Antrasen (DMBA) secara In vivo dimana hasilnya menunjukkan bahwa ekstrak etanol daun sirsak pada kulit mencit yang diinduksi DMBA ternyata juga dapat menurunkan ketebalan lapisan kulit, jumlah mencit yang muncul nodul, mengurangi volume nodul, luas permukaan luka, dan kerontokan bulu serta perubahan berat badan. Sedangkan penelitian lain yang dilakukan oleh Ulumi (2013) tentang Uji Aktivitas Antitumor
Ekstrak Metanol Benalu Teh pada Kulit Mencit yang Diinduksi 7,12Dimethilbenz( $\alpha$ )Antrasen (DMBA) Secara In vivo juga menunjukkan hal yang sama dimana ekstrak metanol benalu teh yang diberikan pada mencit yang diinduksi DMBA juga dapat mempengaruhi ketebalan lapisan kulit, kejadian tumor (insidensi tumor, mengurangi volume nodul), luas permukaan luka, dan kerontokan bulu, serta perubahan berat badan mencit.

Hasil yang ditunjukkan pada penelitian di atas menjadi bukti ilmiah tentang kekuasaan Allah dalam menciptakan berbagai tanaman sebagaimana yang Allah sampaikan dalam QS. Asy Syuaraa ayat 7-8 yang berbunyi :

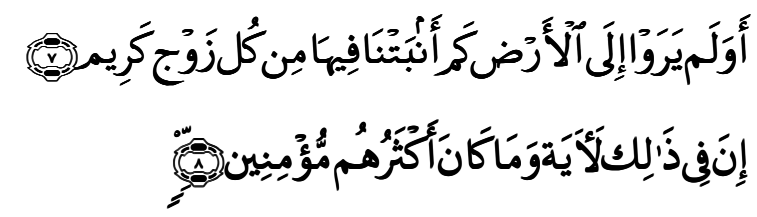

Artinya : "Dan Apakah mereka tidak memperhatikan bumi, berapakah banyaknya Kami tumbuhkan di bumi itu berbagai macam tumbuhtumbuhan yang baik? Sesungguhnya pada yang demikian itu benar-benar terdapat suatu tanda kekuasaan Allah dan kebanyakan mereka tidak beriman".

Ayat tersebut di atas jika dikaji lebih dalam adalah sebuah perintah untuk mengeskplorasi berbagai tanaman yang diciptakan oleh Allah SWT dimana di dalamnya terdapat kekuasaan Allah. Penelitian yang dilakukan merupakan sarana untuk mengetahui hal tersebut dan hasil yang ditunjukkan merupakan jawaban terkait rahasia Allah dalam penciptaan tanaman tersebut. Bahan aktif yang dimiliki oleh sirsak, dan benalu teh dalam mengikat radikal bebas yang tidak stabil sebagai akibat induksi DMBA yang diberikan merupakan bentuk kekuasaan Allah dalam menyembuhkan berbagai penyakit. Selain itu dalam penciptaan tanaman tersebut Allah SWT juga ingin menunjukkan bahwa Allah kuasa dan adil terhadap manusia terkait pemberian penyakit dimana dalam setiap penyakit yang diberikan, Allah SWT juga memberikan obatnya sebagaimana disebutkan 
dalam Q.S Asy-Syu'ara ayat 80 yang berbunyi

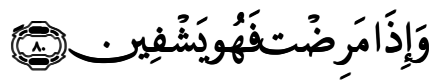

Artinya : "Dan apabila Aku sakit, dialah yang menyembuhkan aku,"

\section{KESIMPULAN}

1. Kadar MDA pada tumor kulit mencit yang diakibatkan pemberian ekstrak etanol daun sirsak (Annona muricata L) dan ekstrak metanol benalu teh (Scurulla atropurpurea) berbeda-beda.

2. Kadar MDA terendah (34.95 nmol/g) terdapat pada DS3 yang berasal dari mencit yang diinduksi DMBA $25 \mu \mathrm{g} / 100$ $\mu \mathrm{l}$ aseton dan diberi ekstrak etanol daun sirsak $60 \mathrm{mg} / \mathrm{KgBB}$.

\section{SARAN}

Perlu dilakukan penelitian lebih lanjut terkait dosis yang efektif dan gen tertentu yang berperan dalam memicu tumor kulit.

\section{DAFTAR PUSTAKA}

Adewole OS, and Caxton AE. 2006. Morphological Changes and Hypoglycemic Effects of Annona muricata Linn (Annonaceae) Leaf Aqueous Extract on Pancreatic B-cells of Streptozotocin- Treated Diabetic Rats. African Journal of Biomedical Research, 9:173-187.

Akrom. 2012. Mekanisme Kemopreventif Ekstrak Heksan Biji Jinten Hitam (Nigella Sativalor) Pada Tikus Sprague Dawleydiinduksi 7,12 Dimethylbenz(A)Antracene: Kajian Antioksidan dan Imunomodulator. Disertasi.Program Doktor Ilmu Kedokteran Dan Kesehatan Fakultas Kedokteran Universitas Gadjah Mada. Yogyakarta.

Chang F. 2003. New Adjacent BisTetrahydrofuron Annonaceous Annona muricata L. Journal of Plant Medical 69 : 241- 246.

Dandekar S, Sukumar S, Zarbl H, Young L, and Cardiff R. 1986. Specific Activation of The Cellular Harvey-Ras Oncogene in Dimethylbenzanthracene-
Induced Mouse Mammary Tumors. Mol CellBiol 6:4104-4108.

Fessenden R, dan Joan. 1999. Kimia Organik. Jakarta: Penerbit Erlangga.

Kardinan A. 2004. Pestisida Nabati ; Ramuan dan Aplikasi. Yogyakarta : Penebar Swadaya.

Nugroho YA, Nuratmi B, dan Suhardi. 2000. Daya Hambat Benalu Teh (Scurrulla atropurpurea) terhadap Prolofrasi Sel Tumor Kelenjar Susu Mencit (Mus muculus L) C3H. Cermin Dunia Kesehatan 127: 15-17.

Ohashi K. 2003. Indonesian Medicinal Plants XXV. Cancer Cell Invasion Inhibitory Effects of Chemical Constituents in the Parasitic Plant Scurrula atropurpurea (Loranthaceae). Chem Pharm Bull. 51(3): 343-345.

Sani YMSYM. 2013. Uji Aktivitas Antitumor Ekstrak Etanol Daun Sirsak (Annona muricata L.) pada Kulit Mencit (Mus musculus) yang Diinduksi 7,12Dimetilbenz $(\alpha)$ Antrasen (DMBA) secara In Vivo. Skripsi. Jurusan Biologi Fakultas Sains dan Teknologi Universitas Islam Negeri Maulana Malik Ibrahim. Malang.

Sulistio H. 2008. Inhibisi Aktivitas Prolifrasi Sel dan Perubahan Histopatologik Epitelial Mukosa Nesofaring Mencit C3H D dengan Memberikan Ekstrak Benalu Teh. Tesis. Program Pasca Sarjana. Universitas Diponegoro. Semarang.

Susilowati. 2010. Efek Kemopreventif Ekstrak Metanol Kulit Kayu Nangka (Artocarpus heterophylla lmk.) pada Karsinogenesis Kanker Payudara Tikus Betina yang Diinduksi DMBA. Skripsi tidak diterbitkan. Surakarta: Fakultas Farmasi Universitas Muhammadiyah. Surakarta. Surakarta.

Tambunan G. 2009. Diagnosis dan Tatalaksana Sepuluh Jenis Kanker Terbanyak di Indonesia.Yogyakarta : EGC

Ulumi AM. 2013. Uji Aktivitas Antitumor Ekstrak Metanol Benalu Teh (Scurulla atropurpurea) pada Kulit Mencit (Mus musculus) yang Diinduksi 7,12Dimethilbenz $(\alpha)$ Antrasen (DMBA) secara In vivo. Skripsi. Jurusan Biologi Fakultas Sains dan Teknologi 
Universitas Islam Negeri Maulana

Malik Ibrahim. Malang.

Woo MH. 2000. Astrilobins C And D : Two

New Cytotoxic Mono-

Tetrahydrofuran Annonaceous

Acetogenins From Asimina Triloba

Seeds. Journal of Biorganic and

Medicinal Chemistry 8 : 285- 290. 